* Izv. prof. dr. Stjepan Radić, Katolički bogoslovni fakultet u Đakovu Sveučilišta J. J. Strossmayera u Osijeku, Petra Preradovića 17, p. p. 54, 31400 Đakovo, stjepan.radic987@gmail.com

\title{
Ontološka dimenzija (moralnoga) čina u svjetlu grijeha i krivnje*
}

\author{
STJEPAN RADIĆ* \\ • https://doi.org/10.31823/d.27.2.7 • \\ UDK: $111^{*} 27-423.35$ • Izvorni znanstveni rad \\ Primljeno: 16. lipnja 2018. • Prihvaćeno: 13. lipnja 2019.
}

Sažetak: Usuprot uvriježenom mišljenju kako metafizička refleksija o moralu i temeljnim principima ne pomaže osobito, cilj je priloga osvijetliti ishodište moralnoga diskursa koji nužno započinje od metafizičke raščlambe ljudskih čina. Metoda koju autor u razmatranju čina primjenjuje jest analitičko-ontološka, štoviše, ona se ovdje pokazuje ključnom. Tako se u prvom dijelu analize prispjelo uvidima koji neporecivo upućuju na to da se ljudski čini daju svrstati u dvije osnovne skupine: tzv. tranzeuntna (prijelazna) djelovanja na jednoj te imanentna (unutarnja) na drugoj strani. Temeljna pak karakteristika obaju vrsta djelovanja, odnosno činā jest promjena, bilo da je riječ primjerice o pjevanju, $\mathrm{cr}$ tanju, plivanju (tranzeuntna) ili pak razmišljanju, htjenju, ljutnji (imanentna). Navedeni primjeri pokazuju da se jedno stanje stvarnosti premjestilo, promijenilo u drugo. Predočena pak analiza poslužila je pozadinom razmatranja pojmova grijeha i krivnje, koji svojom opsežnošću i kakvoćom nužno potpadaju u jednu od predočenih vrsta djelovanja. Ubojstvo, krađa, preljub kao tranzeuntni te mržnja, pohlepa, požuda kao imanentni prijestupi, tj. grijesi, za posljedicu takoder

\footnotetext{
* Autor članka, ujedno i član Uredničkoga vijeća časopisa Diacovensia, zbog mogućega sukoba interesa izuzet je iz procesa evaluacije ovoga članka te prihvaćanja i odlučivanja o njegovu objavljivanju. Članak je nastao na tragu predavanja koje je autor održao na Teološko-pastoralnom seminaru za svećenike Đakovačko-osječke nadbiskupije koji se od 13. do 15. rujna 2016. godine održavao u Đakovu u organizaciji Đakovačko-osječke nadbiskupije i Katoličkoga bogoslovnoga fakulteta u Đakovu. Svi sudionici toga skupa obvezali su se objaviti svoje radove u ovom časopisu. (Zapisnik sjednice Uredničkoga vijeća časopisa Diacovensia - Klasa: 612-10/19-01/02. Ur. broj: 2121-32-01-19-04)
} 
imaju - kao i djelovanja općenito - promjenu, poglavito na unutarnjem te zatim, posljedično, i na vanjskom području. Uz iskustvo grijeha nužno se veže doživljaj krivnje. Članak, tako, završava razmatranjem o fenomenologiji krivnje kao unutarnjem činu. Ona se paku svojem početnom dijelu očituje kao preuzimanje odgovornosti te u završnom kao pokajanje, koje uz oprost krivnji u konačnici daje potpuni smisao.

Ključne riječi: čini - djelovanja, promjena, događaj, grijeh, razlika, odgovornost, krivnja, (po)kajanje, oprost.

\section{Status quaestionis: Ontologija ljudskoga čina}

U najopćenitijem, ontofilozofskom smislu ljudske čine, odnosno djelatnosti možemo svrstati u dvije temeljne cjeline, izvanjsku i unutarnju. Prva, izvanjska actio transiens odgovara onim djelovanjima koja se u ontologiji nazivaju tranzitivne akcije ili prijelazna djelovanja. To su ona djelovanja koja započinju u djelatniku i završavaju u izvanjskoj stvarnosti koju mijenjaju. Čin koji ima svoj konkretan, vidljiv učinak: pjevati, moliti, pisati, voziti. Unutarnja pak djelovanja ili, u ontologiji nazvane, imanentne operacije, actio immanens, jesu ona djelovanja koja započinju i načelno završavaju u subjektu. To su manje-više sve mentalne akcije, načelno spoznatljive samo djelatniku koji ih započinje i provodi, kao što je misaona aktivnost u svim njezinim vrstama, nadalje djelatnosti htijenja, tj. nakane, preko mržnje, zavisti do činâ kao što su primjerice slušanje, gledanje i osjetilno zapažanje uopće... Zadnje tri pak samo naizgled djeluju kao izvanjske, međutim u svojoj su osnovi unutarnje djelatnosti jer ne proizvode promjenu u izvanjskom smislu, na onaj način, kao što je to slučaj s prvim, tranzitivnim akcijama. ${ }^{1}$

$\mathrm{Na}$ temelju netom predstavljene podjele, za uočiti je temeljni pojam koji se kroz nju provlači, promjena. Obje vrste čina, barem i neznatno, čine promjenu, bilo u zamišljaju neke ideje bilo u paljenju svjetla. Promjenu ovdje shvaćamo u smislu događanja, pri čemu neka stvarnost, filozofski bitak, prelazi iz jednoga stanja u drugo. Tako, u pogledu vanjskih, tranzitivnih akcija, paljenje svjetla čini promjenu za mrač$\mathrm{nu}$, odnosno slabo osvijetljenu prostoriju, dok se u pogledu unutarnjih, imanentnih operacija ta promjena događa s obzirom na ljudsku svijest - već spomenuto rađanje ideje, potenciranje ljutnje itd. ${ }^{2}$ Također je neosporno da tranzitivne akcije imaju utjecaja na osobu, tj. mijenjaju njezinu svijest, međutim one se upravo i razlikuju

\footnotetext{
${ }^{1}$ Akcija, u: S. KUTLEŠA (ur.), Filozofski leksikon, Zagreb, 2012., 13. Ovdje se referiramo na sveobuhvatni pojam djelatnosti, odnosno akcija (lat. actio). Usp. također F. RICKEN, Allgemeine Ethik, Stuttgart, 2003., 95-96.

${ }^{2}$ Suvremeni njemački filozof F. Ricken razlikuje u oslanjanju na G. H. Wrighta četiri vrste elementarnih promjena te posljedično četiri vrste djelovanja, za koje pak nema precizne nazive, već ih jednostavno opisuje. Usp. F. RICKEN, Allgemeine Ethik, 95. Poanta je dakle sa svakom od njih da jedno stanje stvari premješta (mijenja) u drugo.
} 
od unutarnjih, imanentnih po tome što je ta promjena dovršena vanjskim činom. Svakako, i više je nego jasno, da se time pojam promjene u ontološkom smislu ne iscrpljuje. Promjena je jedna od osnovnih danosti bitka uopće i događa se na svakom koraku, a ne dakle samo s obzirom na agirajući, tj. djelatni subjekt. ${ }^{3}$

Djelomično naznačen pojam događanja, odnosno događaja kao takvog, predstavlja najosnovniju ontološku odredbu ljudskoga čina i njemu nužno pripadajuću promjenu. Drugim riječima, događanje je ona zadnja ontorealna kategorija na koju se ljudski čin i s njim promjena kao njegova posljedica mogu svesti. Ono u sebi obuhvaća ljudsko djelovanje i promjenu zajedno. Dokaz je tomu i svakodnevno uvjerenje praćeno jasnom jezičnom distinkcijom: kada smo nešto učinili ili činimo, bilo na unutarnji ili pak vanjski način, tada velimo da se to dogodilo. U suprotnom događanje negiramo. Primjera koji idu toj tvrdnji u prilog jest mnoštvo: situacije u kojima je na djelu unutarnje previranje, u smislu donošenja odluke, predočavamo upravo na takav način, naime da se to $u$ nama uistinu odvilo, kao i slučajeve s vanjskim djelatnostima - izgovorena ili napisana riječ, izvršeno djelo - čija dokazivost upravo i ovisi o kategoriji objektivnoga, tj. očitoga događanja. Štoviše, u nezanemarivom broju slučajeva, kada nam je do isticanja objektivnosti događaja krajnje stalo jer smo u njegovu činjeničnost neporecivo uvjereni, redovito dodajemo već spomenuti izraz zaista, uistinu se dogodilo...

Ljudsko djelovanje is njim posljedično promjena svoje cjelovito značenje dobivaju dakle pojmom događaja, tj. događanja kao takvoga. On je ovdje, kako vidjesmo, jedna vrsta legitimacije, potvrde učinjenoga. U tom smislu pojedini će filozofi metafizičari djelovanja držati kao podklasu događanja. ${ }^{4}$ Ipak, slično kao i s promje-

\footnotetext{
${ }^{3}$ Nije stoga nikakvo čudo što promjena predstavlja jedan od temeljnih filozofskih, ali i fizikalnih problema bivajući predmet prijepora kroz cijelu povijest filozofske misli. Polarizirajućih stavova pri tome nije manjkalo bilo da ju se uzimalo temeljnim ontološkim načelom (Heraklit) bilo da ju se u potpunosti negiralo (Parmenid). Potonje je za filozofiju (i fiziku) utoliko zanimljivije i izazovnije jer se odvažuje (racionalno) negirati evidentni fenomen, naime samu promjenu. Međutim čini se da je upravo u tome poanta: ono što se (pomalo prisilno) nameće kao realno, ne dopuštajući pri tome nikakvu upitnost, obično se pokazuje samo kao doksa, tako da iza njega stoji nešto fundamentalnije, ono dakle što samo po sebi želi biti skriveno i ne svima očito. Čini se da je upravo to bila pozadina Parmenidova (kao i cijele elejske škole) negiranja kretanja.

${ }^{4}$ The Oxford Handbook Of Metaphysics, M. J. LOUX, D. W. ZIMMERMAN (prir.), New York, 2003., 381. To čini npr. Davidson: »Following Davidson (1967), most philosophers regard actions as a subclass of events, those where it makes sence to ask why the agent did what she did.« Isto. Sigurno, ne slažu se svi filozofi da se djelovanja jednoznačno mogu svesti na događaje kao takve. Neki djelovanja vežu isključivo za djelatnika, tj. subjekt, argumentirajući to pojmom uzročnosti. Pojedini naime (kao von Wright; Bach) razlikuju zbog toga djelatnikovu od događajne uzročnosti. Usp. isto, 382. Svakako, prema našem mišljenju ovdje nije riječ o krajnje protivnim mišljenjima, već više o svojevrsnom načinu, tj. ishodištu promatranja, pri čemu oba stava upućuju na događanje kao takvo. $\mathrm{U}$ tom smislu mi ostajemo pri početnom stavu.
} 
nom, pojam događaja ne iscrpljuje se potpuno u ljudskom djelovanju, jer padanje kiše, protjecanje rijeke, podrhtavanje tla također su događaji. Tako je onto-logička veza između (ljudskoga) djelovanja i događanja u izvjesnom smislu asimetrična: svako je ljudsko djelovanje događanje, međutim i više je nego jasno da se svako događanje ne dade svesti na ljudsko djelovanje. Nadalje, događanje, tumačeno s pomoću filozofskoga modela gibanja, ne smije se također pojednostavljeno svesti na puku materijalizirajuću aktivnost dinamike, odnosno doslovnoga kretanja jer izložba slika, parkirani automobil, sunčanje jesu u jednakoj mjeri događanje kao i hod o točke $A$ do točke $B$, padanje snijega ili pak igranje picigina. ${ }^{5}$ Netom navedeni aspekti događanja, statično i dinamično, imaju jedinstvene konstitutivne elemente, zajedničke ujedno i specifično ljudskom djelovanju. To su nositelj događanja, u što možemo ubrojiti uzročnost i njegova svojstva, nadalje prostorno-vremenska dimenzija u vidu tijeka događanja u nekom kontekstu koji mu drago te već spomenuta posljedičnost, tj. promjena koju djelovanje/događaj ima kao svoj učinak. ${ }^{6}$

Na temelju predstavljene analize može se primijetiti da svako ljudsko djelovanje sadrži, na manje ili više očit način, netom navedene konstitutivne elemente događa-

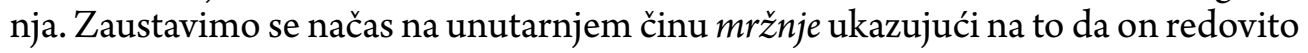
ispunjava te sastavnice, iako one ne izbijaju na površinu onom snagom i jasnoćom kao što je to slučaj s izvanjskim, tranzitivnim akcijama. ${ }^{7}$ Mržnja nečega/nekoga jest događanje, konkretno i realno. S obzirom na nositelja ovdje je riječ o osobi, kon-

\footnotetext{
${ }^{5}$ Svakako, kritika koja se ovdje može (s pravom) uputiti jest ta da se i mi ovdje služimo reduktivnim modelom objašnjenja, odnosno da smo spomenute fenomene akcije, djelovanja, mirovanja itd. jednostavno sveli na događanje pri čemu nam je (ta) redukcija poslužila kao univerzalizirajući princip s pomoću kojega smo navedene fenomene s lakoćom protumačili. Odgovaramo: prigovor stoji, ali samo ako isključimo filozofsko-ontološki, odnosno fundamentalno-logički pogled na stvarnost, koji ide do svojih krajnjih granica, pri čemu, dakako, i to je temeljni argument, pojmovi poput djelatnosti, promjene, događanja nikako nisu istoznačni, već se, slijednom kako su navedeni, upotpunjuju u sebi bliskoj sljedećoj kategoriji. Slično je primjerice i s pojmovima bitka, biti, bića, odnosno postojanja, života, svijesti itd. Stoga filozofski govor o prvotnim uzrocima (...) svih stvari nikako nije redukcionistički upravo iz razloga što filozofija pretpostavlja govor o svemu o čemu se uopće dade racionalno misliti, odnosno svodi neku stvarnost na posljednje ishodište (njezina) bitka.
}

${ }^{6}$ E. RUNGGALDIER, C. KANZIAN, Grundprobleme der Analytischen Ontologie, Paderborn, 1998., 182-198. Navedeni autori iscrpno razlažu ontološku kategoriju događanja iznoseći pri tome njegove mnoge problemske aspekte, i na ontološkoj i na s njom povezanoj jezičnoj ravni. Podjelu u vidu konstitutivnih elementa koju smo mi predložili u određenom je smislu vlastita, ne zapostavljajući temeljna (ontološka) svojstava događanja kao takvog, koje su spomenuti autori detaljno razradili s obzirom na mnoge druge autore i pravce. Za neke autore pojedina svojstava ne će ulaziti u konstitutiv događaja. Tako primjerice u predstavljanju autora Jaegwon Kima naši autori za konstitutivne elemente iznose nositelja, svojstva i vremenski tijek. Usp. isto, 188.

${ }^{7}$ Time smo ujedno naznačili i ontološku strukturu grijeha kao takvoga. $\mathrm{O}$ tome nešto više u drugom dijelu rada. 
kretnoj individui i zbog toga joj se posljedično i pripisuje odgovornost. ${ }^{8} \mathrm{Uz}$ nositelja događanja navedena je ovdje ujedno i kategorija uzročnosti kao jedno od važnih svojstava događanja, pri čemu je osoba kao takva, dakle u svojoj cjelini, temeljni uzročnik, a ne tek neki dio nje. U tom smislu ostavlja osoba u svakom svojem činu (bio on dobar ili zao) prepoznatljiv trag. Određeni se problem nameće s obzirom na prostorno-vremensku dimenziju. Ako tranzitivne akcije podliježu prostornovremenskoj kategoriji, imanentne operacije čine se od toga oslobođene. Međutim samo naizgled! Prostorno-vremensku smještenost, primjerice toga unutarnjega događanja (mržnje), ne dokazujemo isključivo na način puke smještenosti u našoj svijesti, jučer oko 18 sati, iako to po sebi ne bi bilo pogrješno. Prostorno-vremenska dimenzija ovdje se u svojoj osnovi tiče kontekstualnosti, tj. relacijā na temelju kojih je mržnja zaista na djelu. Ona mržnji pridaje u izvjesnom smislu objektivnost. Pojam intencije, odnosno relacije ovdje igra presudnu ulogu, i s obzirom na ontološku kategoriju samoga događanja i s obzirom na njezine već spomenute prostornovremenske smještenosti. Nema naime mržnje kao ni uostalom njezine suprotnosti - ljubavi koja nije usmjerena prema nečemu/nekomu. Pa ako je u pitanju i cijeli svijet. Intencija dakle upućuje na (konkretan) objekt, više ili manje preciziran, po kojemu je mržnja kao i svaka druga mentalna aktivnost odrediva. Tako kada mrzimo te s obzirom na mržnju dokazujemo prostorno-vremensku kategoriju toga događanja, tada se svakako oslanjamo na vrijeme kada smo se tomu prepustili te $\mathrm{u}$ odnosu na koga/čega (primjerice nepravedan sustav). Upravo taj jasni referentni okvir ciljnosti mržnje sa sobom nužno nosi kategoriju smještenosti i vremenitosti, odnosno i, drugim riječima, da taj netko ili nešto zaista postoji u vremenu i prostoru. Zaključimo: to da mentalna aktivnost, tj. događanje poput mržnje, ima svoju prostorno-vremensku dimenziju znači da ona nije fiktivna, odsanjana i slično, već da se itekako i vrlo precizno mogu odrediti, takoreći, reference (moje) mržnje, i s obzirom na prostor, tj. smještenost i osobito s obzirom na vrijeme. Vrijeme se ovdje dakle tiče objektivnoga tijeka jednoga razdoblja i time stanja u kojem smo se zade-

\footnotetext{
${ }^{8}$ Važan aspekt koji kod pojma nositelj djelovanja valja uzeti u obzir jest cjelovitost u smislu materije i forme te s njima povezane nauke o aktu i potenciji. Naime upravo se time rješava problem svođenja konstitutivnih elemenata nekoga događanja na njegova (vidljiva) svojstva. Uzmimo tako primjer događaja protjecanja, tj. tijeka neke rijeke: nositelj kao konstitutivni element toga događanja ovdje nije tek korito koje takoreći drži, nosi cijelu rijeku, već voda (koja teče) čija je mogućnost aktualizirana u protjecanju, bilo u već spomenutom vidu uobičajene rijeke odnosno potoka bilo pak i tek samo u vidu slapa kao 'mjesta gdje se voda tekućica prelijeva niz kamenje, stijene, ob. visine' (V. ANIĆ, Veliki rječnik hrvatskog jezika, Zagreb, 2009., 1424.). Slično će biti i s čovjekom kao nositeljem događanja mîsli: nositelj mentalnih aktivnost poput mišljenja, odnosno govora jest čovjek kao osoba koji je u mogućnosti konkretno događanje dovesti do izvršenja, odnosno aktualiziranja, a ne tek neki njegov dio, pa bio on određen baš za tu djelatnost kao npr. jezik, usta i sl.
} 
sili, koje pak potvrđuje već spomenutu smještenost, tj. kontekstualnost i time ide u prilog realnosti samoga događanja.

Ontološka dimenzija čina s obzirom na predočene aspekte upućuje dakle na njegovu realnost, koja se ne dade osporiti. Tim više što se vlastito (unutarnje/vanjsko) događanje dovodi u vezu s doživljajem vlastite osobnosti, odnosno vlastitoga ja(stva). Doživljavam svoje djelovanje ponajprije i jednostavno zato što jesam ili, drugim riječima, djelujem zato što tomu djelovanju moj ja, konkretan i odrediv, stoji u osnovi što će pak nužno utjecati na to da djelujem na onakav način kakav zapravo jesam. Te jednostavne postavke/uvidi upućuju na to da vlastito ja(stvo) (su)spoznajem i kao jedno sebstvo upravo po vlastitom djelovanju i komuniciranju s okolinom. ${ }^{9}$ Uvid o postojanju neporecivoga odnosa između subjekta kao nositelja i čina kao izvršene kategorije upućuje u isto vrijeme i na kvalitativnu (moralnu) dimenziju, i samoga djela i karaktera koji ga je izvršio. Time nužno stupamo na područje moralnosti ljudskih čina.

\footnotetext{
9 Time smo dotaknuli problem istaknut u nekih suvremenih filozofa duha, koji subjektivnost, odnosno sebstvo svode na model samoreprezentacije. Ukratko: prema suvremenom njemačkom filozofu T. Metzingeru, osoba doživljava i spoznaje svoje jastvo na »ne-pojmljiv način interne Samo-reprezentacije «. Jastvo tako nije supstancijalno središte naše materijalno-duhovne prirode, koje na cjeloviti i jezgroviti način biva podloga našim naravnim, voljnim i intelektualnim težnjama, već u određenom smislu konstrukt, model, ovisno o djelatnostima čiji je ono nositelj. Tako, jednostavna postavka da nas naša djelovanja čine onakvim kakvi jesmo ovdje se uzima doslovno, štoviše, krajnje radikalno, jer prema Metzingeru naše djelatnosti, vanjske i unutarnje potpuno oblikuju model našeg ja prema kojemu se ono jedino spoznaje i, što je presudno, dade odrediti kao konačno. Dakle, kao što smo drugima protumačivi jedino na način kakvu sliku, odnosno model o sebi ostavljamo, isto je i sa samospoznavanjem, tako Metzinger. Usp. J. QUITTERER, Unser Selbst im Spannungsfeld von Alltagsintuittion und Wissenschaft, u: G. RAGER, J. QUITTERER, E. RUNGGALDIER (ur.), Unser Selbst - Identität im Wandel der neuronalen Prozesse, Paderborn, 2002., 116-123. Metzingerova koncepcija ima iznenađujućih sličnosti s budističkim i hinduističkim stavovima o ja koji se temelje na Budinu opovrgavanju fiksnoga ja. Svakako, i više je nego očigledno, da se uvjerenja toga njemačkoga filozofa o jastvu kose s kršćansko-tomističkom (u osnovama i augustinovskom) koncepcijom, koja jastvo promatra u bitnom odnosu prema pojmu duše, dakle kao supstancijalno središte vlastite osobnosti, svakako povezano s našim djelatnostima, ali u konačnici nesvodivo na njih. To je ja(stvo) dakle osnova (vlastitim) djelatnostima, od njih se ipak i razlikuje jer se u njima u potpunosti ne iscrpljuje. Tako, odgovaramo Metzingeru, kao što, istina, sebe spoznajemo prema modelima koje nudimo, isto tako u najdubljoj osnovi vlastita bića spoznajemo jezgru koja se ne dade u potpunosti poistovjetiti s tim modelima, već se od njih razlikuje. Ne mislimo pri tome tek u odnosu na moralni aspekt (stanja u kojima se tješimo da ipak nismo tako loši kako se čini ili pak hvalimo da smo dobri kakvim se predstavljamo), već krajnje ontološki: ta je razlika - nas i naših modela - realna i jasna te vlastitom introspekcijom uočljiva. Zaključujemo: postoji jedan ja, kao supstancijalna jezgra i nositelj svih naših karakteristika i djelatnosti, koji se pak od njih i razlikuje. Ja nisam moja djelovanja, iako za njih, jasno, nosim odgovornost. Tim više i upravo zbog toga!
} 


\section{Konstitutivni elementi nekoga moralnoga čina}

Nakon što smo pokušali u najosnovnijem obrisu predstaviti ontološku dimenziju čina, i u njegovoj unutarnjosti i u njegovoj izvanjkosti, dovodeći ga u bitnu vezu s događanjem, nameće se potreba, s obzirom na zadanu temu, prijeći iz metafizike u moralnost pretpostavljajući njihovu nužnu upućenost. Naime, oslanjajući se na izvode koje smo učinili do sada - ljudski čini kao događaji koji imaju svojega nositelja, $t j$. uzročnika, $s$ bitnom prostorno-vremenskom kategorijom, te $u$ konačnici posljedicom, tj. promjenom - razmotrit ćemo u daljnjem na temelju čega tim činima nužno pripisujemo kategoriju moralnosti, tj. moralno ispravnoga odnosno neispravnoga, dobroga odnosno zla. Drugim riječima, pitanje kojim se u ovom naslovu želimo baviti glasi: Što sve ulazi u moralnu refleksiju nekoga čina, odnosno koje njegove elemente, s obzirom na događanje uopće, moramo uzeti u obzir da bismo ga sagledali cjelovito u moralnom pogledu? U razmatranju moralnosti nekoga čina uzima filozofsko-teološka te posebice tomistička tradicija tri temeljna elementa: materijalnost, tj. objekt učinjenoga, namjeru ili nakanu s kojom se nešto učinilo odnosno čini te okolnosti u okviru kojih je neko djelovanje izvršeno ili se još uvijek izvršava. ${ }^{10}$ Već i letimičan pogled na ta tri elementa upućuje na prožetost ili, bolje, kompatibilnost metafizike i etike, odnosno metafizičke u odnosu na moralnu refleksiju. Potonja se naime oslanja na netom iznijete postavke o činu jer joj metafizička raščlamba čina, tj. ljudske djelatnosti kao događaja predstavlja ishodište i time daje utemeljenost. U tom smislu etika ne može ostaviti metafiziku po strani u ime neke quasi objektivnosti, konkretnosti ... kada joj, kako naznačismo, ona nužno stoji u pozadini.

Više je nego jasno da je objekt učinjenoga - kao ishodište moralnoga sagledavanja - sam događaj, tj. događanje, koje smo promotrili u njegovoj metafizičkoj strukturi. Namjera je vezana uz subjekt kao nositelja učinjenoga ili s pozicije metafizičke raščlambe nositelja događanja u njegovim temeljnim karakteristikama (svjesnost, sloboda), dok se okolnosti tiču spomenute prostorno-vremenske kontekstualnosti i svih čimbenika koji su s tim vezani i na taj način imaju utjecaja na konkretni čin. Etičko-moralni aspekt dakle nastavlja na metafizički s razlikom premještanja problema na formalni karakter djela, odnosno vidik pod kojim ga želimo razmotriti moralna ispravnost odnosno neispravnost, dobro odnosno zlo te subjekt kao takav. Jer, ako smo u metafizici imali za nju specifičnu indiferentnost, u pogledu etike i još više moralne teologije ta ovdje izostaje iz jednostavnoga razloga što se djela moraju promotriti pod vidom moralnoga dobra i zla. ${ }^{11}$ Time smo također odškrinuli vrata

${ }^{10}$ Usp. H. DOBIOSCH, Das Gesetz der Gradualität im Spannungsfeld von Gerechtigkeit und Liebe, u: C. BREUER (prir.), Ethik der Tugenden, St. Ottilien, 2000., 90.

${ }^{11}$ Suvremeni moralni teolog I. Fuček priklanja se načelno tezi da je svaki ljudski čin ujedno i moralni čin. Pri tome upozorava da se to izjednačavanje događa s obzirom na ljudsku osobu, odnosno či- 
horizontu pitanja i problema sažetih u pojmove slobode, odgovornosti, grijeha, krivnje, koje ćemo netom kasnije pokušati detaljnije razmotriti.

Objekt učinjenoga prvotna je kategorija u odnosu na namjeru i okolnosti. Važnim se nameće ponovno upozoriti na tu činjenicu iz razloga što je na djelu svojevrsno premještanje očišta s objekta na subjekt i s njim vezane okolnosti, odnosno situacije i kontekst. To se premještanje, s obzirom na etičku refleksiju, događa još u neokantizmu te poglavito $\mathrm{u}$ formalnoj etici Max Schelera, da bi se u suvremenosti posebno učvrstilo u anglosaksonskom području, u kojem prevladavaju inačice situacionističkih i relativističkih etičkih koncepcija. ${ }^{12}$ Potonje stavljaju u pitanje objektivni moral is njim vrijednosti po sebi, upravo zbog već spomenutnoga osporavanja objekta kao temeljnoga ishodišta moralnoga čina. Svakako, problem se ne rješava konačnim, radikalnim zauzimanjem jedne od strana. To ne čini ni katolička moral-

njenicu da se svaki hotimično izvršen čin u konačnici može promotriti u perspektivi postavljenoga (moralnoga) ideala. Svakako, time se ne oduzima pravo razmatrati čin u njegovoj ontologiji, koja sama po sebi nije prvotno moralnoga karaktera - ono dakle što smo mi u prvom naslovu učinili - jer ontološka razjašnjenja utiru put spoznajno-jezičnoj analizi ljudskoga čina, koja je također nužna i legitimna: uzmimo primjerice pojmove poput nakane, ideje, mišljenja. Njihovo razmatranje pod vidom ispravnoga određenja i definiranja, međusobnoga razlikovanja i konačno referiranja na konkretan entitet jest nužan korak u kasnijoj moralnoj refleksiji. To pak - ispravno određenje i definiranje, kao i međusobno razlikovanje - nije specifično moralnoga, već spoznajno-ontološkoga karaktera. Potvrdu netom izrečenoga donosi i spomenuti teolog kada upozorava na to da su na djelu dva različita područja. U tom smislu, priznajući njihovu upućenost, držimo dakle s druge strane da je sasvim legitimno promotriti ih zasebno, s jasnom naznakom kada je riječ o jednom, a kada o drugom. Tako ovaj teolog: » (...) je li svaki 'ljudski čin' ujedno i 'moralni čin'? Tako postavljeno pitanje u sebi uključuje drugo pitanje: je li svaki ljudski čin učinjen bar s nekom sviješću na moralnu normu tj. kriteriji koji ravna tim činom pa zato potpada pod moralni red? (...) Recimo odmah da o tom pitanju tijekom povijesti postoje razna mišljenja teologa. Ali na taj način postavljena pitanja donekle nas odvode od cjeline, tj. od osobe počinioca, na promatranje čina kao čina - čina u sebi - čime se mi ne bavimo «. I. FUČEK, Moralno-duhovni život. Grijeh i obraćenje, Split, 2004., 19.

${ }^{12}$ Čitava je plejada suvremenih anglosaksonskih moralnih filozofa koji s većim ili manjim razlikama zastupaju i argumentiraju u prilog relativizma (B. Williams) i situacijske etike (R. Hursthouse). R. Hursthouse pripisujemo kategoriju situacijske etike zbog njezina poznatoga stava o pobačaju. Pobačaj se, prema njoj, treba gledati iz ženine perspektive, odnosno situacije, a ne čina koji će ona učiniti ili ne će. Ženu koja se nalazi u težim životnim okolnostima, tj. situaciji kao što su mali prihodi i već dovoljan broj djece, te zaključi da će rođenje novoga djeteta za nju i ostatak obitelji donijeti samo štetu i gubitak, ta situacija opravdava u nakani pobačaja. Usp. D. BORCHERS, Die neue Tugendethik. Schritt zurück zum Zorn?, Paderborn, 2001., 296. Sva promašenost stava spomenute filozofkinje vidljiva je upravo u potpunom odmaku od čina u sebi te inzistiranju na kontekstualnosti, tj. situaciji u slučajevima krajnje moralne osjetljivosti kakav je pobačaj. Tim više što Hursthouse problem samo produbljuje (nikako rješava) svojim daljnjim izvodima pri čemu kao ideal u odluci $z a$ i protiv pobačaja donosi stav, vrlinu koju će žena pri tome zauzeti: ako se ona pokaže hrabra, odlučna i razborita zbog već spomenute situacije, time će, za tu filozofkinju, njezina odluka za pobačaj (ili pak protiv njega) biti opravdanija. 
ka jer, polazeći od objekta, nikako ne isključuje subjekt i s njim kategoriju savjesti. Međutim i s druge strane radikalno odstupanje od objekta vodi u relativiziranje moralnosti kao takve. Upravo se zbog toga - krajnje razboritoga na jednoj, ali i zahtjevom za objektivnom istinom na drugoj strani - čini pogođen put pape Ivana Pavla II., istaknut u njegovoj enciklici Veritatis splendor (Sjaj istine): »Moralnost ljudskog čina prije svega $i$ temeljno ovisi o predmetu što ga je razumno izabrala hotimična volja. (...) Da bi se mogao zahvatiti predmet čina koji mu određuje moralnu kakvoću, treba se dakle smjestiti u perspektivu osobe koja djeluje. (... ) U tom smislu (...) ima konkretnih postupaka koje je uvijek pogrešno izabrati, jer je njihov izbor nered volje, to jest moralno zlo. ${ }^{13}$

Navedena tri konstitutiva s obzirom na moralnost nekoga čina - objekt, nakana, okolnosti - osvjetljuju dakle čin s obzirom na njegovu moralnost i trebaju se, počevši od objekta, uzimati u svojoj sveukupnosti. Međutim daljnje pitanje koje se ovdje postavlja glasi: Koji postupak držimo relevantnim da neki čin u sebi (objekt djelovanja) proglasimo moralno dopuštenim odnosno nedopuštenim, dobrim odnosno zlim? Slično kao i u odnosu metafizike i etike, pri čemu smo utvrdili upućenost etičke refleksije na metafizičku, i ovdje u pomoć zazivamo svojevrsnu interdisciplinarnost unutar samoga filozofijskoga pristupa: tri temeljna aspekta moralnosti nekoga čina svoje daljnje upotpunjenje nalaze $u$ onom što se u filozofskoj etici označava kriterijima za koje je pak odgovoran praktični um. Ti se kriteriji donose i pod pojmom norme praktičnoga uma. Jednostavno rečeno, to hoćemo li neki čin prepoznati i time označiti kao moralno dobro ili zlo ovisi upravo o njegovoj (ne) usklađenosti s moralno-etičkim principima, tj. normama koje, u konačnici, otkrivajući, iznalazi praktični um. Ovdje dolazimo do krucijalnoga problema sadržanoga u pitanju konstituira li, tj. utemeljuje li praktični um (Kant) ili (samo) su-otkriva moralnost $\mathrm{u}$ vidu moralne dobrote ili zloće (sv. Toma). Katolička moralka, u bitnome tomistički orijentirana, stavljat će svakako naglasak na otkrivačku dimenziju praktičnoga uma. To međutim, s obzirom i na samog Akvinca, nikako ne znači puko preuzimanje moralnih principa na takav način da praktični um s njima nema ništa osim pukoga zapovijedanja volji u vidu izvršavanja, kao da bi oni već odavno, božanskom uredbom, odnosno principima naravnoga zakona, bili (za njega) zgotovljeni i time podešeni za puko izvršavanje. U tom smislu sam Toma Akvinski i s njim katolička moralka govore o jednoj teonomnoj autonomiji. ${ }^{14}$ Pojam želi ukazati na odnos praktičnoga uma prema univerzalnim moralnim principima, pri čemu se iz toga odnosa porađa čedo savjesti.

${ }^{13}$ IVAN PAVAO II., Veritatis Splendor, Zagreb, 1998. (= VS), br. 78. Usp. također Katekizam Katoličke Crkve, Zagreb, 1994., br. 1761.

${ }^{14}$ Usp. T. BAHNE, Die Klugheit als Handlungsprinzip der praktischen Vernunft, u: C. BREUER (prir.), Ethik der Tugenden, St. Ottilien, 2000., 126. 
Osvrnimo se pobliže na netom donesen pojam teonomna autonomija. Još od skolastike vrijedi da se univerzalni etički principi u konkretnosti spoznaju na način spoznavatelja, pri čemu im se ništa ne oduzima o njihove univerzalnosti i objektivnosti. ${ }^{15}$ To ne znači naše suptilno prepuštanje relativizmu, svojstveno osobito (već spomenutim) suvremenim pravcima, koji, ističući da idu isključivo u prilog osobe, drže da ona shvaća i primjenjuje moralne principe isključivo na svoj kontekstualni način, pri čemu bi upravo sama konkretnost, tj. situacija bila temeljni kriterij moralnosti usuprot, dakle naravnom zakonu i njemu prirođenim univerzalnim principima. Ti se pravci dadu reducirati na pojam moralni relativizam, očit $\mathrm{u}$ inačicama situacionističke etike. Teonomna autonomija nastoji, naprotiv, istaknuti da postoji naravni zakon kao odsjaj vječnoga Božjega zakona, koji je sadržan $u$ i po sebi evidentnim temeljnim moralnim principima. Tako, kada osoba moralno spoznaje, tada ona po vlastitoj prirodi naginje toj spoznaji i time dobru, pri čemu Toma Akvinski misli na jednu intuitivnu, spontanu i u sebi prosvjetljujuću spoznaju dobra. ${ }^{16}$ Konačno, osoba ima jednu prirodnu težnju prema moralnoj istini i ta (težnja) je neosporna. Stoga odgovor na naše prethodno pitanje o otkrivanju ili konstituiranju, tj. stvaranju moralnih normi, bit će taj da osoba, otkrivajući, na određen način sukonstituira moralni princip, jer samim time što ga prvotno spoznaje, nakon toga izriče te u konačnici provodi (dakle, na način spoznavatelja (!)) ona je uključena u taj božanski red stvaranja. Tek u tom tumačenju mogu se, prema našem skromnom mišljenju, shvatiti temeljne biblijsko-teološke postavke o čovjeku kao partneru Božjem i posljedično sustvaratelju. U suprotnom bila bi riječ tek o lijepom, deklarativnom govoru o čovjekovu dostojanstvu. To što se to partnerstvo često shvaća i time radikalizira do potpune neovisnosti ne daje za pravo pribjegavanju drugoj krajnosti koja čovjeku oduzima svaki vid sudjelovanja i odgovornosti u konstituiranju i osobito primjeni temeljnih moralnih principa. Izbjegavajući kazuistiku i rubricizam na jednoj te radikalnu autonomiju suda savjesti i situacionističku etiku na drugoj strani, uvijek i iznova pokazuju se prodornim tumačenja pape Ivana Pavla II. koji pri spoznaji i konkretnoj primjeni univerzalnih temeljnih principa, presudnu ulogu povjerava već spomenutoj savjesti: »Sud savjesti je praktičan sud, odnosno sud koji

\footnotetext{
${ }^{15}$ Jedan od najeklatantnijih primjera toga spoznavanja jest već spomenuto načelo zabrane ubojstva. Počinjenje ubojstva u stanju nužne samoobrane, pri čemu su iscrpljena sva druga sredstava (o) čuvanja vlastitoga života, ništa ne oduzima od cjelovitosti i jasnoće temeljnoga načela, već ga (paradoksalno) upravo potvrđuje: u samoobrani čuvam (svoj, jedan) život. Zaključimo: poanta s univerzalnim moralnim principima nije tek u njihovoj (teološkoj) deduktivnosti koja bi se po načelu algoritama i formula, konačno, svojevrsnoga misaonoga konstrukta jasno i nedvosmisleno primjenjivala u konkretnim životima, već su to načela koja u konačnici ipak ostavljaju mjesto glasu savjesti, štoviše, ako treba, i uzmiču da bi do izražaja došla upravo ona, odnosno da bi se dovoljno jasno mogao čuti njezin glas.
}

${ }^{16}$ Isto, 127. 
obznanjuje što čovjek treba činiti i ne činiti, ili pak vrednuje djelo koje je čovjek već učinio. (...). To prvo načelo praktična razuma pripada naravnome zakonu, dapače tvori sam njegov temelj, budući da izražava ono izvorno svjetlo o dobru i zlu, odraz stvoriteljske mudrosti Božje koja, poput neuništive iskre (scintilla animae), blista u srcu svakog čovjeka. (...) Tako savjest oblikuje moralnu obvezu svjetlu naravnog zakona (...) Univerzalni karakter zakona i obveze (time op. a.) nije poništen, nego radije priznat, kada mu razum određuje primjene u konkretnoj stvarnosti. $\ll{ }^{17}$

\section{Grijeh i s njim vezana krivnja s obzirom na moralnost i ljudsku djelatnost uopće}

Kako se iz dosadašnjih izvoda dalo uočiti, veliku smo pozornost u ontologiji čina posvetili onomu što nazivamo objekt učinjenoga, odnosno samom djelu. Nije teško zaključiti da će jedna ispravna ontologija grijeha svoje utemeljenje imati u objektu učinjenoga. Objekt, odnosno sama djelatnost, čin kao takav jest dakle osnova sagledavanja grijeha. Kako naznačismo, taj se objekt procjenjuje prema principu ispravnoga odnosno neispravnoga, dobroga ili lošega, ovisno o tome u kojem je stupnju princip povrijeđen. Upravo se u tu filozofsku strukturu povrede principa djelovanja - mislimo pri tome prvotno na univerzalne etičke norme - uklapa za teologiju specifičan pojam grijeha, odnosno narušavanje odnosa s Bogom. Jer je osnovna teološko-biblijska postavka o grijehu ta da on predstavlja narušeno povjerenje prema Bogu kao osobi, a ne tek (i ne samo) povredu principa. ${ }^{18}$ Ipak, pojam principa ovdje je utoliko važan jer se Bog sam pokazuje kao ishodište svakoga principa, bilo moralnoga bilo logičkoga. Jer kada primjerice (namjerno) vrijeđamo zdravu logiku, tj. zdrav razum, vrijeđamo $u$ isto vrijeme i samoga Boga. Isto je tim više s grijehom.

Povreda principa, $t$. norme i s njom narušavanje povjerenja prema Bogu predstavlja cjelovito teološko-biblijsko sagledavanje grijeha. Upravo u tom, kako ga nazvasmo, cjelovitom teološkom sagledavanju grijeha očituje nam se njegova ontologija. Hotimično ubojstvo, krađa, pedofilija, spomenimo samo najistaknutije, kao povrede temeljnih principa, predstavljaju eklatantno odbacivanje Božje spasenjske ljubavi, odnosno raskid odnosa s Njim, što za posljedicu ima odbacivanje Njega samoga. Istina, važno je upozoriti i na sljedeće: iako blisko vezani, te je pojmove nužno i razlikovati (povreda principa, povreda povjerenja). Moralno neispravnim činom narušavamo princip nekoga djelovanja, grijehom narušavamo povjerenje, iako svaki od njih dijelom sadrži značenje i onoga drugoga. Stoga, iako postoji zajedničko

\footnotetext{
${ }^{17}$ VS, br. 59.

${ }^{18}$ Utoliko sakrament pomirenja ne može biti svediv na govorenje istine o sebi, već je riječ o svijesti i time priznanju narušenoga odnosa prema Bogu, izvoru svakoga oprosta i pomirenja.
} 
područje (moralnost) koje ta dva pojma dijele, ipak, svaki od njih zadržava vlastitu ontologiju, odnosno specifični referentni okvir značenja.

Teologija će u svjetlu božanske objave (Biblija) i naravne spoznaje (učiteljstvo) pojam grijeha dalje razlagati u njegovoj specifičnoj naravi: teški i smrtni na jednoj te laki grijesi na drugoj strani, nadalje tu je pojam istočnoga grijeha i njegov odnos prema ljudskoj naravi, odnosno zajednici u kojoj pojedinac stasa; nepreskočivi su također i grijesi struktura te drugi, sekundarni pojmovi koji se u moralnoj teologiji vežu uz grijeh kao što su bliža i daljnja grješna prigoda, napast, kušnja itd. Navedene specifikacije pojma grijeha, kao i netom istaknuta njegova odrednica s obzirom na povredu principa i narušavanje povjerenja svoje ishodište nalaze u trima temeljnima starozavjetnima pojmovima za grijeh: peša (prekršiti red, pobuniti se protiv autoriteta) hatta (promašiti cilj i time vlastiti život) te awon (krivnja nastala iz počinjenoga zla i to prvotno u odnosu prema Bogu). ${ }^{19}$ Uočljivo je da ti biblijski pojmovi korespondiraju s onim što smo nazvali ontologija čina jer u svojoj najdubljoj osnovi dodiruju istovremeno objekt i nositelja (subjekt) s presudnom teološkom komponentom - odnos prema Bogu, pri čemu bi u suprotnom ostao samo nedopušteni čin.

Daljnji biblijski aspekt grijeha, povezan s netom izloženim pojmovima te onim što nazivamo grijehom prvih roditelja, možemo promotriti kroz izričaj dokidanja razlike $i$ različitosti. ${ }^{20}$ Zaustavimo se učas na tome, tako važnom, a tako - s obzirom na suvremenost i postmodernu - inflatornom i dvoznačnom pojmu razlike i različitosti. Pojam različitosti postao je mantra kojom se osobito politički, ali i drugi sustavi legitimiraju, pri čemu pak, ne uviđajući, sami često sudjeluju u dokidanju svake istinske različitosti. Problem koji ovdje želimo istaknuti jest taj da spomenuti sustavi ističu i time nameću razliku koja je konstrukt. Razliku ovdje shvaćamo u vidu potrebne odijeljenosti i svojevrsnoga odmaka. U suprotnom razlika te naravna drugotnost ne odgovara svojoj izvornosti i prirodnosti te kao takva sebe dovodi do

${ }^{19}$ Usp. I. FUČEK, Grijeh i obraćenje, 231. Usp. također I. ŠAŠKO, »Smiluj mi se, Bože, po milosrđu svome « (Ps 51). Vjernički vapaj grješnika, u: Živo vrelo 33(2016.)3, 2-7., ovdje 3.

${ }^{20}$ Pojam, u ovom kontekstu, potječe izvorno od hrvatskoga teologa I. Šaška. Spomenuti autor govori u osnovi o čovjekovoj težnji za dokidanjem razlike između njega i Boga, odnosno o njegovu (čovjekovu) neprihvaćanju vlastitih granica. Misao spomenutoga autora proširujemo upozoravajući da svako brisanje razlika (početak je, dakako, u grijehu) za posljedicu ima kaotičnost sustava i time svojevrsnu destrukciju. Osim područja kulture i društva, o kojima govorimo u tekstu iznad, na važnosti granice i ograničenja te njihova pridržavanja upućuju mnogi drugi sustavi. Uzmimo za primjer područje gramatike is njom pojam definicije. Potonji se u svojoj osnovi sastoji od dviju lat. riječi de i fineo, što će reći o-graničiti. Tako, do pravoga značenja, a time i određenja nekoga entiteta, sustava itd. možemo tek onda doći ako ograničimo njegov infinitum, ono neodređeno. Ljudska osoba je dakle u svim područjima života upućena na de-fineo. Izdvajanje područja morala is njim vezano sustava zapovijedi i zabrana iz toga ne može u konačnici imati nikakav drugi učinak doli upravo štetu za ljudsku osobu. 
apsurda - brisanje istinske i za ljudskost naravne razlike. Prvi znak gubljenja razlike sadržan je u zahtjevu za izostankom (moralnih) normi i načela, put koji nas - paradoksalno - ponovno dovodi do grijeha prvih roditelja. Moralne norme i načela naime uspostavljaju dužnu različitost $\mathrm{u}$ hijerarhijskom smislu - stablo s kojeg se ne smije jesti - što je pak dalje osnova kulturnoga poretka uopće. Suvremenost je dakle obilježena jednom demagogijom različitosti, suprotnoj temeljnim antropološkim i kulturološkim odrednicama, u kojima su upravo norme i pravila jamčile kulturni poredak, zasnovan na dužnim razlikama. Opasno stanje gubljenja razlika - pod već spomenutom krinkom zalaganja za njih - dosiže, čini se, svoj vrhunac. Primjera je na pretek, počevši od ljudske seksualnosti, preko umjetnosti do, konačno, suvremene (pop) kulture: svima je zajednički upravo zazor od (moralnih) normi, onoga dakle na čemu počivaju razlike. O gubljenju pak osjećaja za grijeh da i ne govorimo.

Slično kao i u govoru o ljudskom činu općenito - pri čemu smo pojam subjekta i s njim samosvijesti i slobode nužno pretpostavili - tako je is grijehom. Grijeh, koliko god to banalno i pojednostavljeno zvučalo, čini subjekt, osoba, konkretna individua, odrediva u vremenu i prostoru. Kao i kod čina, osoba je i ovdje nositelj grijeha. Pojam naznačene gradualnosti tu igra također presudnu ulogu. Ne pripisuje se odgovornost i time grijeh uvijek na jednoznačan način. Oni ovise o onom što nazivano stupanj ubrojivosti, koji pak u svojem cijelom opsegu predstavlja jastvo i s njim slobodnu volju. Primjetno je dakle kako smo u ovoj raščlambi, tj. ontologiji grijeha i krivnje, učinili mali odmak od djela, tj. čina i približili se subjektu i svemu onom što je njime uključeno. $S$ pojma grijeha prispjeli smo na pojam grješnosti. Kao što je neupitno da konkretan subjekt ćini, proizvodi djela, vrijedi i obratno: djela sačinjavaju i određuju subjekt ili, preciznije, njegov karakter. Jer svako dobro stablo rada dobrim plodovima, a nevaljalo stablo rada zlim plodovima (usp. Mt 7, 17). Mi nismo naša djela, ali se po njima prepoznajemo i u velikoj mjeri određujemo.

Polazeći od te pretpostavke, suvremena moralna, osobito anglosaksonska filozofija inzistira u moralnoj kvalifikaciji na deskriptivnim moralnim pojmovima, onima naime koji u svojoj formi i sadržaju opisuju djelo i karakter istovremeno. Slično kao i kod tzv. slabe i jake misli u filozofiji, pobornici tzv. karakternih moralnih pojmova inzistiraju na tome da se prednost dade pojmovima lažljivac, kradljivac, preljubnik, za razliku od djela, tj. narušenih principa: laži, krađe, preljubi. Drukčije rečeno, u osobnoj refleksiji nad nekim mogućim činom moralni si akter ne treba prvotno postaviti pitanje narušavam li, odnosno povređujem li ja svojim djelom neki moralni princip, nego kakva osoba, odnosno karakter ja postajem tim činom. ${ }^{21}$ Temeljni argument koji pojedini američki teoretičari ovdje donose jest motivacijsko-psihološki i u tom je smislu i za autora tih redaka prilično jak. Pitanje, odnosno dvojba o narušavanju principa (mi-

${ }^{21}$ Usp. K. P. RIPPE, P. SCHABER, Einleitung, u: ISTI (prir.), Tugendethik, Stuttgart, 1998., 9. 
slimo na individualnu situaciju) ostavlja redovito dojam svojevrsnoga međuprostora (da ne kažemo praznine) između mene kao subjekta i konkretnoga čina. Pitanje pak, odnosno dvojba o promjeni karaktera nekim činom pokazuje da spomenuti čin u bitnome utječe na moj karakter, koji se promjenom stvarnosti (jer je nešto učinjeno, promjena kao konstitutiv čina) i sam po tom činu mijenja. Najjednostavniji primjeri to pokazuju: krađa kao vanjski i mržnja kao unutarnji čin - kradljivac i mrzitelj. Štoviše, unutarnji to pokazuju na bolji i jasniji način: kada želimo ići do kraja u očitovanju, tada često umjesto izraza mrzio sam kažemo obuzela me mržnja, što će reći da sam se pretvorio u mrzitelja (osobe/sustava). Ili pak s primjerom laži: u provali iskrenosti bilo u psihoterapiji ili pak ispovijedi znamo doživjeti da izraz gotovo sam od sebe proteče u formi ja sam postao (običan) lažov, ne tek lagao sam.

Prijelazom s pojma grijeha na pojam grješnosti i time na subjekt i njegov karakter koji nekim činom, u ovom slučaju grijehom, biva promijenjen došli smo do pojma krivice. Slijedom dosadašnjih razmatranja s obzirom na čine krivnja je, slično kao i odgovornost, kauzalno pribrojavanje počinjenih djelā konkretnom subjektu. ${ }^{22}$ Biti uzrokom nečasnih djela jest dakle početni uvjet opravdanoga doživljaja krivnje. Ovdje se nameće svom jasnoćom i nužnošću određenje osobe kao duhovnoga i time po sebi cjelovitoga entiteta, upravo iz toga razloga što stupnjevitost krivnje ne ovisi samo o slobodi, odnosno raspolaganju njome (suprotnost joj je fizička prisila), već i o doživljaju vlastite osobnosti, odnosno i, jednostavno, o samosvijesti kao takvoj pri čemu pojam prisebnosti (biti-kod-sebe, biti-svjestan) ovdje isplivava svom snagom. To pak s obzirom na pojmove samosvijesti, odnosno doživljaj sebe kao cjelovit entitet dalje znači da zao čin nije učinio netko u meni ili pak jedan dio mene, već ja sām, redovito s punom svijesti o spomenutom činu i vlastitoj osobnosti. Upravo će u tom smislu dakle ovisiti i stupanj krivice, od potpune preko djelomične do one u kojoj je ona svedena na minimum - lakše ili teže mentalne, odnosno psihičke retardacije i sl. Tako kada samosvijest, tj. doživljavanje sebe, stavljamo ispred slobode, tada time pokazujemo da svijest vlastitoga ja njoj stoji u pozadini i to već samom logičkom nužnošću. O ontološkoj da i ne govorimo. Jer u spomenutim retardacijama nije tek na djelu (pojednostavljeno) gubitak slobode, već ono što njoj radikalno prethodi - gubitak svijest o vlastitom ja. ${ }^{23}$ Time svakako ne pretpostavljamo jednu

${ }^{22}$ H. JONAS, Das Prinzip Verantwortung. Versuch einer Ethik für die technologische Zivilisation, Frankfurt a. Main, 2003., 172.

${ }^{23}$ Svakako ovdje valja upozoriti na razliku između trenutačnoga na jednoj i habitaulanoga (trajnoga) izostanka odnosa prema vlastitoj osobnosti, tj. gubitka svjesnosti kao takve, na drugoj strani. Potonje, habitulano, predstavlja spomenuto dugoročno narušeno mentalno, odnosno psihičko zdravlje, dok trenutačno pomračenje uma pri kojem se čine najteži zločini (ubojstvo i silovanje) nikako ne potpadaju pod tu kategoriju i krivica im se ubraja na potpun i cjelovit način. Uzgred rečeno, osobe (bolesnici) s nekom kroničnom duševnom bolesti u redovitim slučajevima i ne predstavljaju osobitu opasnost za okolinu. 
statičnu i dovršenu koncepciju osobe, već ju zajedno s M. Schelerom, među osta$\mathrm{lim}$, određujemo kao »svijetu-otvoreno te slobodom, smislom i vrijednošću nedovršeno biće ${ }^{24}{ }^{24}$ Naznačeni pojam ubrojivosti svijesti koji, kao i sloboda, ima svoju stupnjevitost ovdje je presudno važan upravo zbog stupnja pripisivanja odgovornosti i s njom krivnje za neko (moralno) djelo. Zaključimo, krivnja će dakle ovisiti ponajprije o stupnju samosvijesti te posljedično o slobodi koja je pri tome bila na djelu na jednoj i težini materije (grijeha) na drugoj strani.

Otklanjajući umišljaj da smo tim (jednostavnim) uvidima i riješili problem krivnje, ostajemo i sami svjesni da je pojam krivice, i u filozofskom i u psihološkom smislu, u sebi i dalje duboko složen fenomen iz jednostavnoga razloga što on uz objektivnu odgovornost uključuje i osobni, tj. vlastiti doživljaj koji se zrcali u tom fenomenu. Dovoljno je pri tome spomenuti doživljenu traumu (u bilo kojem stadiju života) da bi se uvidio sav raspon toga, specifičnoga ljudskoga doživljaja. Tako usuprot radikalnim koncepcijama koji pojam krivnje kao, uostalom, i slobode, savjesti i drugih bliskih fenomena ljudskosti tumače krajnje determinirano i time redukcionistički (odgoj, prirodno nasljeđe, kulturni poredak) i time ga drže pukim društveno-psihološkim konstruktom, mi se priklanjamo onim strujama u filozofiji koji krivnju smatraju jednim od važnijih aspekata morala te ljudskoga života uopće pri čemu redovito fenomen savjesti (u većini slučajeva zbog krivnje) dolazi do svojega očitovanja.

Krivnju is njom odgovornost ovdje smo promotrili u uskoj vezi. Koliko god međutim slične i time upućene jedna na drugu, one se ne daju poistovjetiti, osobito ne zamijeniti jedna drugom. Svijesti krivnje svakako prethodi doživljaj odgovornosti. On mu dakle leži u osnovi, međutim valja upozoriti na to da krivnja nije u svim slučajevima nužna posljedica odgovornosti po principu: ako smo odgovorni, tada smo (sigurno) i krivi. Jer, biti odgovoran za nešto još uvijek ne znači biti i kriv zbog nečega, već samo to da smo u najvećoj mjeri i neovisno o svim okolnostima krajnji začetnici nekoga djela ili - rečeno svakodnevnim govorom - mi/ja preuzimam(o) to djelo na sebe. Postaviti se odgovornim u nekom djelu, odgovarati za njega znači, slično kao i kod krivnje, sebe odrediti kao individua supstantia, nepriopćiva (u metafizičkom smislu, dakako - ja ne mogu djelovati u drugom ni drugi u meni) i time biti sposoban uzrokovati izvanjske i unutarnje djelatnosti, pri čemu se otvaram mogućnosti njihova objektivnoga određivanja u vidu dobrih ili zlih djela, shodno sudu vlastite savjesti i objektivnom moralnom redu. Upravo je to očitovanje kriterij po

${ }^{24}$ U. KRUSE-EBELING, Max Scheler: Die Reue, u: R. SPAEMANN, W. SCHEIDLER (prir.), Ethik. Lehr- und Lesebuch, Stuttgart, 2006., 466-470., ovdje posebno 468. 
kojem (u najdubljoj nutrini) možemo provjeriti snosimo li potpunu, djelomičnu te snosimo li uopće odgovornost (i naknadno krivicu) za pojedina djela. ${ }^{25}$

Doživljaj i priznanje krivce dovršava se konačno u kajanju kao njezinoj naravnoj posljedici. Vezano uz to, upravo kajanje ima za pojedine filozofe, poput M. Schelera, središnji ćudoredni i time pozitivni smisao za ljudsku osobu i društvo u cjelini. ${ }^{26}$ Drukčije rečeno, dopuštajući fenomen krivnje u refleksivnom smislu, tj. promišljajući o nekom prošlom djelu, u isto vrijeme očitujemo žal za počinjenim, što u izvjesnoj mjeri predstavlja kajanje. Doživljaj krivnje is njim kajanja jesu u konačnici jedan samoprijekor jer, kako vidjesmo, počinjenje djela nije tek narušavanje principa, već u isto vrijeme i oblikuje karakter - ako se zaustavimo samo na prijestupu kao takvom, apstrahirajući čak i od pojma grijeha. Smisao kajanja stoga nije nivelirati, osobito ne brisati događaje iz prošlosti. Ponirući dublje i time propitujući pojmove grješnosti, krivnje i kajanja, uviđamo da pojam sjećanja ovdje također ima nezaobilaznu ulogu. Kajanje, među ostalim, priziva sjećanje o prošlom, odnosno ono ga sjećanjem posadašnjuje. Tek to posadašnjenje, tj. imati učinjeno, rečeno, propušteno pred očima, omogućuje pravu refleksiju nad onim što se dogodilo. Prakse vlastitoga, unutarnjega propitivanja, ispovijedi ili psihoterapije jesu oblici čuvanja spomena o prošlom $\mathrm{s}$ obzirom na vlastitu grješnost. $U$ tom smislu lijepo ističe $A$. Vučković da »kajanje nije brza operacija odstranjivanja krivnje jer je ono proces kojemu treba vrijeme $\ll .{ }^{27}$ I s obzirom na vlastito iskustvo, odnosno osobni zahtjev da se zbog počinjenoga trebamo kajati i s obzirom na drugoga kada se od njega zbog počinjenoga zlodjela očekuje (po)kajanje. Iskustvo krivnje i, posljedično, kajanja, kao svojevrsne spoznaje grješnosti, ima dakle za posljedicu ponajprije uspostavljanje novoga odnosa $s$ prošlim. Prošlost se, istina, ne briše, ali joj se prisjećanjem i preobrazbom daje novi smisao. U društvu međutim u kojem je na »'cijeni brzina reakcije, atraktivnost čak i svojevrsna provokativnost « (B. Horvat) prisjećanje o kojem ovdje govorimo stalno gubi bitku. A ono je naše najnaviknutonosnije držanje i time osnova mišljenja uopće, upozorava s pravom još Platon. Zasigurno u govoru o prošlosti nikako ne

${ }^{25}$ Davanje dovoljnih razloga s obzirom na odgovornost ovdje predstavlja sagledavanje (vlastita) čina sa svih njegovih aspekata, pri čemu nam je ta unutarnja refleksija početak buđenja savjesti. Svakako bi najlakše i najjednostavnije bilo naginjati dvama krajnostima: potpuno ustezanje od činova kod kojih postoji mogućnost pogrješke (grijeha) i shodno tomu samo hladna primjena principa da se ne bi pogriješilo (osjetljiva savjest) na jednoj ili pak potpuno otupjela savjest bez ikakvoga propitivanja na drugoj strani. Iako se druga krajnost čini opasnijom, prva je također svjetlosnu godinu udaljena od ideala kršćanskoga morala.

${ }^{26}$ Usp. U. KRUSE-EBELING, Max Scheler: Die Reue, 467. Usp. također M. SCHELER, Von Ewigen im Menschen, 1. Kapitel: Reue und Wiedergeburt, u: R. SPAEMANN, W. SCHEIDLER, Ethik. Lehr-und Lesebuch, 471-478.

${ }^{27}$ A. VUČKOVIĆ, Kajanje i novo srce. O otkriću sebe u kajanju, u: Živo vrelo 30(2013.)2, 2-5., ovdje 5. 
smijemo izgubiti iz vida budućnost jer kajanje utječe i na oblikovanje karaktera u budućnosti te povrh svega na odnose koji se ubuduće stvaraju.

Kajanje međutim po kojem krivnja postaje aktualizirana, ovdje ne shvaćamo isključivo u teološkom pogledu okajavanja grijeha, već i u specifičnom moralno-pravnom: naime da počinjeno zlo ubojstva, teške krađe ili krivokletstva zahtijeva restituciju, obnovu narušenoga stanja i time nadoknadu za počinjeno zlo, osnovna je moralno-pravna postavka. Na tome, među ostalim, počiva i pozitivno pravo. Restituciju pak nije moguće uspostaviti tek hladnim/formalnim priznanjem ubojstva, nezainteresiranim vraćanjem novca ili pak naknadnim banalnim iznošenjem istine. Doživljaj krivnje i s njim kajanja ima samo onda smisao i vrijednost kada iza njega stoji cijela osoba spremna dalje na izvršavanje (ovdje djelomično spomenutih) raspoloživih načina nadoknade, odnosno zadovoljštine za učinjeno, pa bila ona i sama spremnost na izdržavanje zatvorske kazne koju je odredio pravni sustav ili pak drugi slični oblik spremnosti na lišavanje slobode koje su odredile druge nadležne institucije ako nisu povrijeđeni kazneni zakoni neke zemlje. ${ }^{28}$

\section{Mjesto zaključka}

Ako priznanje krivnje ima za naravnu posljedicu kajanje, oboje su pak u svojoj osnovi upućeni prema pojmu oprosta kao jednoj vrsti sućutnost, bilo da ih izričemo prema samima sebi (sebi opraštamo), drugim osobama (drugima opraštamo) ili u konačnici i najčešće prema Bogu (Njega molimo za oprost). Oprost o kojem je ovdje riječ u konačnici je uvijek prilika za novi početak. To nije ponavljanje, već se

${ }^{28}$ Tim drugim institucijama koje propisuju kazne svojim članovima prvotno možemo ubrojiti Crkvu. Također vezano uz pravni sustav, odnosno zakone pojedinih zemalja ovdje se možemo ukratko dotaknuti i smrtne kazne te upozoriti na svu njezinu promašenost. Naime upadljivo je kako je ta praksa jedna od zajedničkih odlika država koje se po svemu stavljaju (i žele postaviti) nasuprot jedna drugoj (primjer: SAD, Sj. Koreja). Dakle riječ je o rasponu zemalja od liberalno-demokratskih do totalitarnih. Zanimljivost je međutim tim veća da smrtna kazna ne samo da frapantno podsjeća na koncept osvećivanja u arhaično-primitivnim društvima (osvećuje se zajednica prema počinitelju da bi izbjegla međusobna osvećivanja), od kojega se u čak i nekim liberalnim društvima smrtnom kaznom još uvijek nismo udaljili, već u svojoj osnovi negira svaku mogućnost istinskoga pokajanja. Sigurno, pokajanje, pa i iskreno, može se dogoditi tik pred izvršenje smrtne kazne. Međutim zatvoreniku se (i u tom slučaju), ma kakav zločinac bio, smrtnom kaznom oduzima svaka mogućnost da njegovo pokajanje bude aktualizirano, tj. ostvareno u promjeni karaktera za budući tijek života jer je srž pokajanja, kako pokazasmo u gornjem tekstu, uspostava novoga odnosa prema prošlosti da bi upravo budućnost imala smisla. Smrtna kazna dakle dovodi pravni sustav do apsurda - negira ono što se samim pravom želi postići, restituciju u vidu istinskoga pokajanja, koje može biti aktualizirano tek u budućnosti. Time dolazimo, kako to briljantno uviđa Scheler do suza, ali i radosti pokajanja. »Ovo je veliki paradoks pokajanja, da u suznom pogledu promotri unazad, ali svakako radosno i snažno prema budućnosti te djeluje na obnovu i oslobođenje od ćudoredne smrti.« $\mathrm{M}$. SCHELER, Vom Ewigen im Menschen, 476. 
dade usporediti sa svakim novim jutrom, koje je u biti uvijek novo započinjanje. Jer, ne zaboravimo, početak daje uvijek novu priliku i pri tome mnogo toga spašava. Nasuprot pak tomu premještanje/prebacivanje odgovornosti za grijeh i krivnju na unutarnje odnosno vanjske čimbenike u osnovi zaprječuje suočavanje s vlastitom prošlošću. Samim time i pojam oproštenja ovdje je doveden u pitanje: čemu bih si trebao oprostiti, (a zatim i meni Bog) ako se grijeh tiče tek urođene odnosno stečene mane, koja po sebi predstavlja tek sklonost. Gurajući pak pojam grijeha na marginu, čovjek se polako, ali sigurno prepušta rijeci banalnosti bez jasnoga smjerokaza čemu, kamo, zašto. Sitnice sigurno ne čine ono prevažno u životu. Međutim život i svakodnevica bez sitnica postali bi jedno veliko ništa. U tom smislu, umišljajući sebi da vladamo svojim životom i osobnošću (jer smo se eto oslobodili spona nametnute krivnje o vlastitoj grješnosti, koje su tek obične sitnice kojima ne treba pridavati veliku pozornost), polagano, ali sigurno gubimo kontrolu nad tim istim životom i osobnošću. Narav se navikava na prosječnost koja, istina, ne mora (ali može) voditi u neku osobitu katastrofu, međutim s druge strane ne nudi ni ništa osobito korisno i vrijedno. Jer grijeh kojemu redovito udovoljavamo postaje navika, a navika kojoj se ne opiremo postaje nužnost, kako zgodno ističe kršćanski velikan Augustin. 


\title{
THE ONTOLOGICAL DIMENSION OF THE (MORAL) ACT IN THE LIGHT OF SIN AND GUILT
}

\author{
Stjepan RADIĆ*
}

Summary: Despite the widely held view that a metaphysical reflection on morality and fundamental principles does not help much, the goal of the article is to shed light on the source of moral discourse that necessarily begins with a metaphysical analysis of human acts. The method used by the author in the analysis of the act is analytical-ontological, and, moreover, it is shown to be the key one here. Thus, the first part of the analysis has provided great insights that undeniably reveal that human acts can be classified into two basic groups: the so-called transient (transitive) actions on the one side, and immanent (inner) on the other side. The fundamental characteristic of both types of actions, or acts, is change, whether it is singing, drawing, swimming (transient) or thinking, wanting, anger (immanent). The above examples show that one state of reality has moved or changed to another. The presented analysis served as the background for reflection on the concepts of sin and guilt, which through their complexity and quality necessarily fall into one of the presented types of action. Murder, theft, and adultery as transient, and hatred, greed, and lust as immanent transgressions, i.e. sins, also have as a consequence - as well as actions in general - a change, especially in the internal and then, consequently, also in the external area. The experience of sin is necessarily linked with the experience of guilt. The article, therefore, ends with a reflection on the phenomenology of guilt as an internal act. At the beginning it manifests itself as taking responsibility and, in the end, as repentance, which together with forgiveness, ultimately gives full meaning to guilt.

Keywords: acts - actions, change, event, sin, difference, responsibility, guilt, repentance, forgiveness.

\footnotetext{
* Assoc. Prof. Stjepan Radić, Ph. D., Catholic Faculty of Theology in Đakovo, J. J. Strossmayer University of Osijek, P. Preradovića St 17, P. O. box 54, 31400 Đakovo, Croatia, stjepan.radic987@gmail. com
} 